Article

\title{
Mapping Green Dublin: Co-Creating a Greener Future With Local Communities
}

\author{
Alma Clavin *, Niamh Moore-Cherry and Gerald Mills \\ School of Geography, University College Dublin, Ireland; E-Mails: alma.clavin@ucd.ie (A.C.), \\ niamh.moore@ucd.ie (N.M.-C.), gerald.mills@ucd.ie (G.M.) \\ * Corresponding author
}

Submitted: 18 May 2021 | Accepted: 22 July 2021 | Published: 14 October 2021

\begin{abstract}
Mapping Green Dublin is a transdisciplinary, collaborative action research project led by University College Dublin's School of Geography in collaboration with arts organisation Common Ground, artist Seoidín O'Sullivan, and event facilitators Connect the Dots. It took place in an inner-city neighbourhood of Dublin 8 between 2019 and 2020 and was funded by the Irish Environmental Protection Agency. This article outlines the methodological approach taken to develop a communityled greening strategy that is both inclusive and planning-policy relevant. The first phase of the project involved scientifically mapping the span and territories of trees and greenspace across Dublin 8, identifying their location and quality, greenspace deficits, and future needs. Phase two included a series of curated events from March to August 2020 to map out a proposed process for co-creating urban greening solutions focusing more on local identity and the possibilities for future creation. The scientific data was presented to communities in a way that opened up a creative and supportive space for dialogue on the wider role of trees and greening in enhancing urban resilience. Such a co-created greening plan ensures that interventions respond to neighbourhood needs, have high social and cultural value within the community, and maximise opportunities for community wellbeing. The final phase of the project identified specific areas for focused greening interventions. An important output from this action research project is a co-creation process to enable communities, local authorities, and policymakers to engage with and develop a new governance arrangement for more inclusive and appropriate urban greening strategies.
\end{abstract}

\section{Keywords}

co-creation; Dublin 8; green infrastructure; Mapping Green Dublin; urban governance; urban greenspace

\section{Issue}

This article is part of the issue "Towards Green(er) Cities: Contextualizing Green Benefits for Urban Spaces and Contemporary Societies" edited by Juaneé Cilliers (University of Technology Sydney, Australia).

(C) 2021 by the authors; licensee Cogitatio (Lisbon, Portugal). This article is licensed under a Creative Commons Attribution 4.0 International License (CC BY).

\section{Introduction}

The quality and resilience of ecosystems in our living environments is increasingly recognised as an important determinant of health, quality of life, and overall wellbeing. The Covid-19 pandemic and control measures, including the use of lockdowns, has foregrounded the importance and unequal distribution of good quality environments as citizens became restricted to small areas around their home and more aware of their microgeographies. For those living in cities, and particularly in densely populated neighbourhoods, differential access to quality living and recreational space has been brought into sharp focus, raising significant social and environmental justice concerns (Kayanan et al., 2021). Deep socio-spatial inequalities in housing, health, and income are also clearly manifest in relation to the physical environment (Anguelovski et al., 2019).

The politics and politicisation of urban greenspaces (Oscilowicz et al., 2021) and particularly trees planted along streets (Carmichael \& McDonough, 2018; Rotherham \& Flinders, 2019) in cities across the globe 
points to the need for a new direction towards more just green strategy-making for urban neighbourhoods. The expanding sphere of the environmental justice debate to climate change (Schlosberg, 2013) incorporates recent critiques of green and eco-gentrification. Internationally, many high-profile parks and green public attractions have been criticised for their inequality of access and gentrification effects (Anguelovski et al., 2020; Oscilowicz et al., 2021). Green gentrification is complex, driven in part by economic development and place-making strategies that aim to attract newcomers to particular, often disadvantaged, urban areas but it can also emerge as an unintended consequence of broader climate mitigation and biodiversity strategies. To develop more inclusive and sustainable cities, deeper dialogue and mapping are required to unearth local concerns, histories, and vulnerabilities, and generate appropriate place-based responses (Bodenhamer et al., 2015; Roberts, 2016). This kind of approach would acknowledge that urban processes, such as greening, do not happen in a vacuum but within particular spatial and socio-cultural contexts that can and should be made legible. The social reality for communities impacted by new forms of socio-spatial restructuring needs to be made visible and discussed to clear the way for new approaches, ideas, and action. Co-creation approaches that highlight the greening issues that most affect individual and collective's wellbeing and quality of life, as well as supporting the development of new and the privileging of alternate knowledges can address some of the critiques noted above and build more inclusive engagement.

This article outlines Mapping Green Dublin (MGD), a 24-month project in Dublin, Ireland, that adopted a co-creation approach-between scholars, activists, artists, other formal stakeholders, and residential communities - to develop a neighbourhood greening strategy from the bottom-up, build a community coalition for action, demonstrate to policymakers the value of adopting a community based approach to green strategy making, and feed into the range of plans and policies currently under review and development in the city. Drawing on the work of Mouffe (2007), we aspired to explore how community activism-employing artsbased practices-can play a critical role in subverting the dominant planning hegemony-rigid, neoliberal, and developer driven-and contribute to the construction of new ideas and subjectivities that provide a platform for change. Empowering communities to access, understand, and deploy scientific data to expose deficits, recognise strengths, and advocate for more equal access to greenspace and a high-quality physical environment is highly political but important in developing more inclusive, diverse, and sustainable cities. Through MGD, we developed an approach grounded in iterative dialogue, open creation of, and access to scientific data, as well as arts-based methods and practices. This enabled deeper understanding of the everyday impacts of urban dynamics, particularly in neighbourhoods undergoing rapid socio-spatial transformation; validated more inclusive knowledges and ways of knowing; and, ultimately, ensured that greening interventions are born from and respond to genuine neighbourhood needs. The article situates the project within the burgeoning literature on co-creation in planning and focuses on how new urban actor constellations can support social and environmental justice through more place-based and grounded strategy development and implementation.

\section{Co-Creation and Urban Greening}

Co-creation has become increasingly popular in recent years as a concept, method, and policy tool (Steinhaus et al., 2018), and the associated co-production of knowledge is seen as an approach for the development of inclusive policy and practice. This has been increasingly applied to the development of policy for the delivery of public goods linked to health, education, community services, and planning (e.g., Alford, 2009; Donetto et al., 2015). Such terms are perhaps the most recent iteration of collaborative planning (Healey, 1997) or communicative planning (Innes, 1998), approaches that focus on the social construction of planning and its role in developing shared meaning between different stakeholders. Drawing on Giddens' (1984) structuration theory, collaborative planning is concerned with not just the interplay of different actors in the urban system but with how these interactions are structured by broader institutional designs, values, and systems (Healey, 2003). In a broadly neoliberal political-economic system, institutional designs, what becomes valued, and what is made possible in the urban arena are shaped to a large extent by market forces and the need to accommodate, or at least not antagonise, powerful development actors. Collaborative approaches thus emerge to try to mediate between different perspectives to come to a shared view and create the conditions under which transformative practices can potentially emerge. Understood within this broader framing, co-creation can be understood as a method or tool that enables collaborative planning practices and the development of shared meaning by working towards consensus building. It has the potential to remove the boundaries between experts and citizens and to reconfigure participatory placemaking (Ermacora \& Bullivant, 2016) as a means to achieving more just outcomes.

The growing utilisation and appropriation of co-creation processes in particular has been critiqued by Horvath and Carpenter (2020) who argue that rather than challenging, they can enable co-option by the state. Critiques of contemporary participatory methodologies (Cooke \& Kothari, 2001) and state-led community engagement practices (Fawcett \& Marsh, 2014; Flinders \& Wood, 2014) abound and most focus on the idea that they exist to neutralise dissent through depoliticisation. In some cases, the public engagement activity is outsourced, creating a new role for private consultants in managing public participation and engagement (Brudell, 
2014). Acknowledging these critiques, we argue for a conceptualisation of co-creation that is radically different. Rather than striving for consensus, we propose a co-creation approach that surfaces, acknowledges, and highlights conflict, dissent, and injustices as an important first and necessary step to enable meaningful interactions and forward thinking. This approach may overcome the "mismatches" that occur in participatory planning (Abram, 2011, p. 122) such as that between the public as an idealised, abstract political construct (for the purposes of thinking about how the state works) resulting in well-informed, active, and critical individuals being "worked around" and feeling unheard. Such an idealised notion of the public is also at odds with the deep historical social relations, which are already in place, and the everyday lives of people. Abram (2011) calls for a greater understanding of two models of democracy in planning: an abstract democracy whose public elect representatives but may also sometimes participate directly in certain activities, and inspiring and often distinctive participative actions, where certain people and personalities come together to reach unique outcomes. A more just co-creation process would problematise these two approaches and creatively work through these spaces of engagement.

Co-creation is also seen as a tool of the creative economy, involving art and design-based practices in dealing with big societal changes such as urban regeneration and the transition towards a low carbon economy. This may be seen within a longer history of the arts being given a key role in cultural branding dealing with urban problems, and the need to adopt a culturally informed perspective in urban planning (Florida, 2002; Landry \& Bianchini, 1995). Lees and Melhuish (2015) have critiqued the lack of depth of the social impact of such processes, and the lack of consideration for the problems associated with gentrification and displacement that may come with a culturally informed perspective, citing an unspoken expectation for arts and culture to be uncritical or "minimum risk" (Phillips, 1988/2000, p. 100). Mouffe $(2007$, p. 5$)$ asserts that artistic activism can play a critical role in processes of urban and social justice by subverting the dominant hegemony and contributing to the construction of new subjectivities. Within urban communities, arts organisations often work within spaces of progressive struggle where culture is a critical and crucial component of everyday life (Yúdice, 2003). Through their role as mediators and their practices, groups that are often most disenfranchised or absent from deliberations can be supported and brought in as a way of progressing towards social emancipation, liberation, and activation (de Sousa Santos, 2014).

Across Europe, an array of local governance arrangements-broadly defined as all formal and informal political institutions, processes, and practices involving state and non-state actors-is being experimented with to bridge ecological sustainability and urban social justice (Cook \& McGinn, 2021a) imperatives and shift towards more just and inclusive urban places. For example, the European funded UrbanA project (www.urbanarena.eu) highlights the role of particular individuals or dedicated organisations in systematically connecting actors of different perspectives and acting as intermediaries who can translate between groups' different discourses and rationalities. These can take a variety of formats including working groups within municipalities, private companies, or civil society (Cook \& McGinn, 2021b). A key lesson from their work is that situated or placebased governance interventions should make space for adaptation, experimentation, and meaningful participation, and tap into existing community networks to create new actor constellations before reaching out to state or other actors. Similarly, Lund (2018, p. 5) highlights the importance of creating mechanisms for "citizens themselves [to] invent or articulate new services or products of public value and new ideas about which institutional structures may support such activities," and argues for co-creation processes that move beyond the engagement of professional citizens to adopt more creative and inclusive forms of civic engagement.

Despite the potential positive impacts, realising the potential of such actor constellations in support of social and environmental justice is challenged by the broader political-economic environment. In recent decades, the commodification and financialisation of urban property, land, and spaces has intensified inequality and development pressures being felt by grassroots groups. Recognising the drivers of urban socio-spatial injustices such as neoliberal growth, austerity urbanism, and uneven environmental health and pollution patterns is a significant and vital first step in identifying the barriers to inclusive greening policies and practices. Progress involves challenging the claim that urban greening is a public good for all (Agyeman, 2013; Anguelovski et al., 2020) particularly in a rapidly developing urban context. The business-investor-led imaginary for urban spaces (Amin, 2013; Harvey, 1989; Swyngedouw et al., 2002) and associated assumptions about particular aesthetics can have profound negative implications for inclusion and justice (Lawton, 2019). When a new place-identity, amenity, or infrastructure are driven by city-branding imperatives and policies (Cook, 2008; McCann \& Ward, 2012), the outcome is usually a city that prioritises consumption and investment returns and where everyday lives and activities are of lesser significance. The right to a good quality and fair everyday life for residents and workers cannot be realised only through top-down political imperatives but neither can they simply be a matter of subaltern resistance and social organisation against the state (Datta, 2013). Bringing these two approaches into productive dialogue is critical to realising meaningful and inclusive urban development. The imperative to ensure that greening deficits in urban neighbourhoods are acknowledged, identified, and addressed has never been stronger. However, this process can be highly emotive and sensitive. 
In its most radical form, co-creation approaches would be highly disruptive to existing hierarchical power relations. Drawing on Horvath and Carpenter (2020, p. 22), we acknowledge the importance of cognitive justice-recognising and valuing the co-existence of different forms of knowledge in the co-creation process and the need to develop methodologies that can capture these diverse knowledges from a broad cross-section of individuals and groups. The foregrounding of alternative knowledges disrupts long-standing structural and other power dynamics and is a core element in literatures on de-colonisation and indigenisation in geography. These argue that dominant narratives close down possibilities for thinking and action and that place-based practices should be brought front and centre in debate and practice. However, few examples currently exist of the successful translation and grounding of the principles of such place-based co-creation into an active policy environment for greener, more sustainable, and just urban environments. Paying attention to the broader structural dynamics shaping neighbourhood development trajectories and the inclusion of different sets of actors produces a unique approach to co-creation that is about listening and expanding rather than listening and pushing for consensus. Expansive and open co-creation processes can help to de-mystify the language, policies, and magic of planning policy and practice (Abram, 2011, p. 19), and equip the community with the data and cognitive tools to develop proposals that feed into and have legitimacy within policy-making circles and processes.

We therefore argue for an understanding of co-creation as neither top-down nor bottom-up, but critically and expansively working through the space between policy makers/practitioners and public knowledges and discourses of greening. Through the adoption of a place-based approach to the governance of urban greening that accepts all parties are equal but that different knowledge producers hold different sets of expertise, vertical relationships between researchers/researched and policy makers/practitioners and communities can be transformed and solutions can grow from place.

\section{The Dublin Context}

Since the introduction of the first targeted regeneration schemes in Dublin in the late early 1990s, former industrial and working-class residential parts of the south-west inner city among other places have been under significant (re)development pressure (Kelly, 2014). The Dublin 8 district, traditionally a relatively lowincome, inner-city working-class neighbourhood, provided the spatial context for the MGD project and is an area that has been subject to repeated rounds of policy intervention for more than 25 years (Moore-Cherry et al., 2015). Although some of the most disadvantaged and large-scale public housing complexes in the city are located in the area, the most significant investments have included the establishment of a cluster of technol- ogy start-up companies (the Digital Hub), tourist infrastructure, such as the Guinness Storehouse, and the construction of a new National Children's Hospital. Dublin 8 is increasingly polarised between long-term residents who have experienced sustained disinvestment and the new residential and business gentrifiers. Recent developments have transformed the socio-economic make-up of Dublin 8. By comparison to other areas of Dublin, the area is densely occupied and the composition is dominated by young adults (20-30s) with few children, many of whom live in apartments and are renters (Central Statistics Office, 2016). There are also remnants of old Dublin that include older housing stock in the form of terraced single-family homes and residents that have lived in the area often for many generations. The area is occupied both day and night by workers and residents and carries a heavy traffic burden, particularly to the west side of the study area which is a major traffic artery from the suburbs into the city centre. At present, it is experiencing development pressure as large unused industrial sites (such as Bailey Gibson and Player Wills) are being re-purposed for multi-storey mixed-use buildings. Build to rent and co-living housing developments of significant height and scale, some up to 19 storeys in a traditional two to three storey environments, by international investment companies, do little to address the housing crisis and aggravates what is an already intense politics of housing in the area (Kelly, 2014; Punch, 2014).

At the same time as access to affordable housing and security of tenure is increasingly politicised, in recent years, the attention of the local authority has moved to place-making. This is partly a response to academic and community critiques of the nature of past development that has resulted in a poor quality, exclusionary public realm in the city (Moore, 2008; Van Melik \& Lawton, 2011), as well as a response to more general trends in urban design and planning where urban attractiveness is considered a critical enabler of economic development (Lawton, 2017; Musterd \& Kovács, 2013) and the role of the arts has become an important part of austerity urbanism (Grodach, 2017). The 2015 Liberties Greening Strategy (Dublin City Council [DCC], 2015) has served as a guiding tool to improve accessibility and the quality of existing green spaces, as well as supporting the creation of some new ones in the eastern part of our study area. But in other parts of Dublin 8, there are ongoing local concerns about the visible appearance of the area, the lack of greenspace, persistent intergenerational social problems, and a sense of being left behind (South InnerCity Community Development Association, 2019). Our research suggests that the provision of greenspace per person in the area is approximately $10 \mathrm{~m}^{2}$, the absolute minimum advised by the World Health Organisation (International Society of City and Regional Planners, 2009) and less than half the European average. Despite the formal creation of spaces such as Weaver Park, simultaneously, more informal community greenspaces are being squeezed out. Given the extreme housing crisis, 
arguments frequently pitch the need for housing against the retention of greenspaces, particularly those that are small-scale and community-based. Where particular forms of greenspace, often heavily surveilled, are provided in areas undergoing gentrification, they can serve to further marginalise under-privileged communities (Cole et al., 2019). Triguero-Mas et al. (2021, p. 6) have suggested that, while well intentioned, the Liberties Greening Strategy in Dublin 8 has had similar effects with one planner recognising the need for more "political analysis of how green space could go towards remedying... social issues." It is within this place-based context that the MGD partnership emerged to seek a new approach to greening strategy-making.

\section{Mapping Green Dublin}

MGD began as a broader call for research under the theme "Greening Dublin's Inner City" funded by the Irish Environmental Protection Agency. The call focused on identifying ways to foster increased community engagement with Green Infrastructure (GI) in the urban environment.

\subsection{Creating the Partnership}

The MGD project team comprises UCD's School of Geography, Common Ground arts organisation, Seoidín O'Sullivan (independent artist), and Connect the Dots, bringing together the scientific and technical expertise of geographers with a range of other groups and organisations. The academic team included colleagues with extensive expertise in urban $\mathrm{Gl}$ and a significant track record in mapping and analysing the trees across Dublin city and the surrounding local authority areas. Another academic colleague had extensive experience working on urban governance and had built up productive relationships with artists and social entrepreneurs over a period of more than five years through a previous temporary urbanism project, Granby Park (Moore-Cherry, 2017), and engagement with the not-for-profit A Playful City (Moore-Cherry et al., 2019). Seoidín O'Sullivan had previously engaged with the School of Geography team on the Tree Line and Hard Graft projects-a critical feminist and socially engaged practice of care, exploring the urban commons by collectively grafting, and planting orchards (www.seoidinosullivan.com). During the period when the MGD project proposal was being written, the Hard Graft project was being hosted at Common Ground, an arts organisation based in Dublin 8 that focuses on how the arts can be used politically to view and alter the circumstances in which people live. A track record of network building by the scientific team across the arts, community, and social enterprise sectors for over more than five years was therefore drawn upon for the project.

As a long-standing place-based entity, the Common Ground organisation emerged as critical to the success of the project. Through experience of over a 25-year period in the area, Common Ground have acknowledged how cultural branding can gloss over tensions in contemporary society stating that "whilst consensus forming brands may have a place in the creative economy, in the visual arts, and the community development sector, there is a much deeper alignment with disagreement, dissent, and critique" (Common Ground, 2019, p. 6). Common Ground (www.comonground.ie) sees art as a powerful means of viewing and altering the circumstances in which people live. The creative knowledge practices they support often focus on marginality and critical ecology, making present creative and critical knowledges and ways of knowing that often remain largely unrecognised by the dominant epistemologies of urban planning (de Sousa Santos, 2018, p. 2). Co-creation is a complex and messy process. Drawing out alternative ways of knowing relies significantly on access to a range of stakeholders and trust between them. The long-term advocacy and legitimacy of Common Ground as an organisation grounded in the principles of social and environmental justice helped the project team to identify key stakeholders and also provided rapid access to a wide range of community groups and activists. The independent artist supported by Common Ground also played an important bridging role between the academic members of the team and local residents based on her previous work within the neighbourhood. She also brought expertise in critical and socially engaged arts techniques to the anticipated co-creation process while Connect the Dots brought their wider policy networks and design expertise to the team. MGD was therefore developed and positioned as a collaborative action research project comprised of cartographers, geographers, artists, designers, activists, and residents working together to identify challenges with and propose new ideas for GI in an inner-city neighbourhood.

\subsection{Actioning the Partnership}

MGD was undertaken in three distinct stages (Figure 1), each with its own distinct methodology:

a. Mapping trees: This phase involved digitising Dublin's urban forest, assessing its geographic distribution, and evaluating the associated ecosystem services. This work was completed for the entire DCC area and then in more detail for the Dublin 8 study area;

b. Co-creation: This involved creative participatory deep mapping techniques, critical art engagement practices, and online survey questionnaires to gather community greening recommendations;

c. Action: This used design thinking methods to develop an urban prototyping workshop with members of the community in the area to support them in developing their own greening projects. Qualitative interview techniques were deployed to elicit a policy/practitioner response 


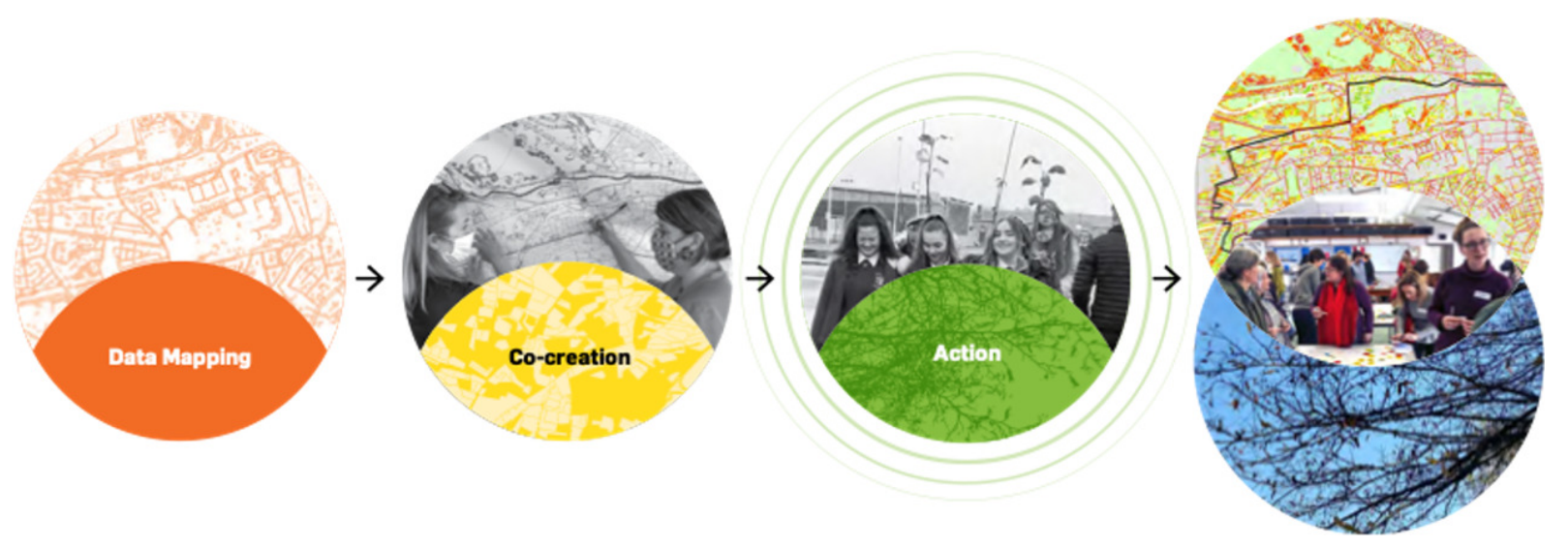

Figure 1. MGD project structure.

to the community recommendations from the cocreation stage. A community-based urban greening strategy was created and included a set of pathways to enhanced greening at neighbourhood level.

\subsubsection{Stage One: Data Mapping}

Information on green cover is available for cities in Europe (Urban Atlas, https://land.copernicus.eu/local/ urban-atlas), including Dublin. These data show relatively large open green areas (minimum mapping unit of $500 \mathrm{~m}^{2}$, with a minimum mapping width of $10 \mathrm{~m}$ ) across the metropolitan area. These data are suitable for largescale urban planning but are of limited value at neighbourhood scales where much of the green cover exists in the form of small parks, private gardens, and cemeteries. Moreover, there is no detailed mapping of trees which form an important component of the GI in urban areas. The MGD project undertook to map the trees in the DCC area to complement existing information on public green areas. These data were needed to evaluate relative provision of Gl in different neighbourhoods and provide a context for assessing the Dublin 8 study area. A variety of datasets were employed to map the Gl across the DCC area, analyse geographic patterns, identify areas of deficit, and evaluate ecosystem services (Table 1). These datasets can be categorised into those directly associated with GI (green cover and trees) and those that provide physical (e.g., rivers and roads networks), environmental (e.g., traffic), and socio-demographic (2016 household and workplace censuses) contexts.

A critical part of the MGD project was the generation of $\mathrm{Gl}$ information that supported the co-creation process. Much of this was provided in the form of maps and tables that showed the uneven distribution of trees and parks across the city (Figure 2) and compared the study area (Dublin 8 , outlined in black) with the surrounding city. Initially, simple counts of trees by height were calculated for public parks, along roads, within private domestic gardens, and within large private spaces (school grounds, golf courses, etc.). Subsequently, tree coverage and open green spaces across the urban landscape were evaluated with comparison to the distribution of daytime and nighttime population. All of the geographic data were integrated using a spatial grid (with a resolution of $200 \mathrm{x}$ $200 \mathrm{~m}$ or four ha). Population data for census' areas, green land-cover, tree location data, and road traffic data were reconfigured with ArcView GIS to create a consistent spatial framework. The Dublin 8 case study neighbourhood spans an area of very low to moderate tree cover. The scientific data produced by the team thus cor-

Table 1. A list of the main sources of information used in the MGD project.

\begin{tabular}{|c|c|c|}
\hline Data & Source & Content \\
\hline Prime2 OSi dataset & Ordnance Survey Ireland & Vector data: roads, building footprints, parks, and water. \\
\hline $\begin{array}{l}2016 \text { household and } \\
\text { workplace censuses }\end{array}$ & $\begin{array}{l}\text { Central Statistics Office } \\
\text { for workplace zones. }\end{array}$ & Residential population data for small areas and work population \\
\hline Dublin city traffic & $\begin{array}{l}\text { Traffic Department } \\
\text { SCATS System }\end{array}$ & Traffic count by hour along sections of the road network. \\
\hline Aerial image & BlueSky (July 2018) & High resolution $(12 \mathrm{~cm})$ data (red, green, blue, and near infrared). \\
\hline Digital elevation model & BlueSky & High resolution ( $1 \mathrm{~m}$ ) Lidar data \\
\hline Tree information & $\begin{array}{l}\text { Fieldwork and } \\
\text { crowd-sourced data }\end{array}$ & Tree dimensions (height and diameter at breast height) and species. \\
\hline
\end{tabular}




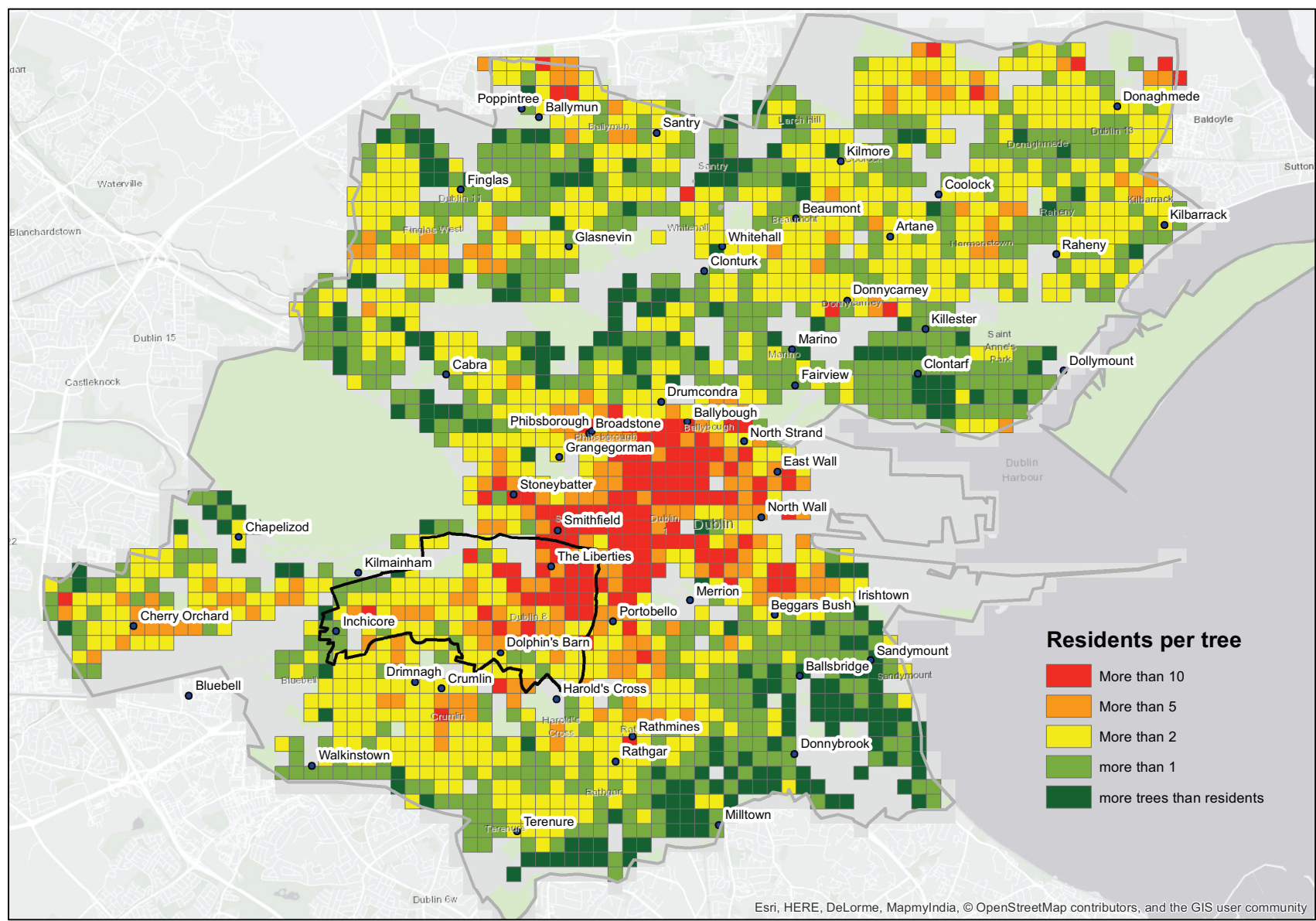

Figure 2. The ratio of trees to residents for populated areas of DCC (residential populations over 100).

related with the lived experience of residents in the area and provided the evidence for them to begin to formally articulate-what until this point had been perceivedneighbourhood deficits.

A simple urban ranking was developed by combining data on population density, tree coverage, and traffic intensity. High rank is associated with high population, high traffic flow, and low tree count, and Dublin 8 scores very highly on all of these measures (Table 2 ). Through this exercise across the city of Dublin, the study area of Dublin 8 was defined as being comparatively underserved in terms of GI. To measure the quality of the urban environment overall, traffic data were used to estimate carbon emission (based on vehicle number and road lengths) and tree data were used to estimate carbon sequestration. The data for the Dublin 8 study area indicate relatively low storage and high emissions, when compared to other neighbourhoods, indicating that air quality is also likely to be relatively poorer in this part of the city.

Engagement with the tree and greenspace data for the entire city and more focused analysis of the study area provided both a greening context and an evidence base to articulate greening inequalities. Maps generated as part of the scientific analysis were made available online and presented at community events. The project team responded to requests from the community at these events for further mapping (e.g., pollution/traffic maps, maps of tree species and carbon sequestration, maps of public land and access, and maps of vacant spaces) as the community became more engaged with the environmental issues and the relative impoverishment of Gl in their neighbourhood. In this way, the mapping process was iterative in nature, aiming to inform and make scientific data openly accessible, but also was deliberately political to level the playing field between

Table 2. Statistics informing neighbourhood ranking of Dublin 8.

\begin{tabular}{lcc}
\hline Measure & Dublin 8 & Surrounding built up area \\
\hline Population density (persons per ha) & 894 & 628 \\
Tree density (trees per ha) & 200 & 273 \\
Average hourly traffic (vehicles) & 295 & 191 \\
\hline
\end{tabular}


the residential community and traditional gatekeepers of data in the city.

\subsubsection{Stage Two: Co-Creation}

The adoption of a community-led co-creation approach to the development of the greening strategy was a conscious and political choice. A number of co-design projects for greening are underway in Dublin at present, but the philosophy of MGD was that the project should be led by community needs and ideas. Hence, developing a process for community engagement became as significant as the final product.

Because of the nature and membership of our project partnership, the MGD co-creation process deliberately aspired to develop alternative ways to listen to community voices and involve them in generating shared understandings of their neighbourhoods and injustices (Horvath \& Carpenter, 2020). Based on the principles of co-creation and tools of both urban social listening (Hollander et al., 2016) and political listening (Brickford, 1996), we designed a co-creation process that had three distinct phases (Figure 3).

The process of listening, expanding, and grounding was developed through a series of activities (Table 3) over a 12-month period for this project. At the heart of the approach was generating new interactions between partners based on dialogue, creating new links (between researchers, researched, artists, and designers), and pro- viding a safe environment for deliberative knowledge production. It was an arena of diverse and at times conflicting interests in that, at different times, co-creation partners had different ideas about the overall narrative to be developed. The co-creation process required time, patience, and sensitivity to all partners and the context of this particular place, necessitating a role for a key bridging individual within the project team.

During the focus groups (listening phase), a range of greening deficits were identified by participants. Clearly defined areas for improvement and areas with strong greening/ecological value for the community were also acknowledged. The key issues to emerge related to inappropriate type/form of greening, greening types being pitted against each other, care and maintenance, urban development pressures, governance of greenspace, and a challenging socio-cultural context for greening. This work informed the planning and preparation for the second event, the community launch.

The community launch event-an all-day open mapping workshop held in a local educational facility-was attended by 80 participants. Large maps detailing roads, landmarks, and all the trees in the area were made available and participants were invited to use stickers to indicate areas of strength (green), potential (yellow), and areas of deficit (red) for up to nine dimensions of greening (trees, greenspace, biodiversity, play, sport, seating, walking, cycling, cars/pollution) that emerged from the earlier deep mapping focus groups. A total of

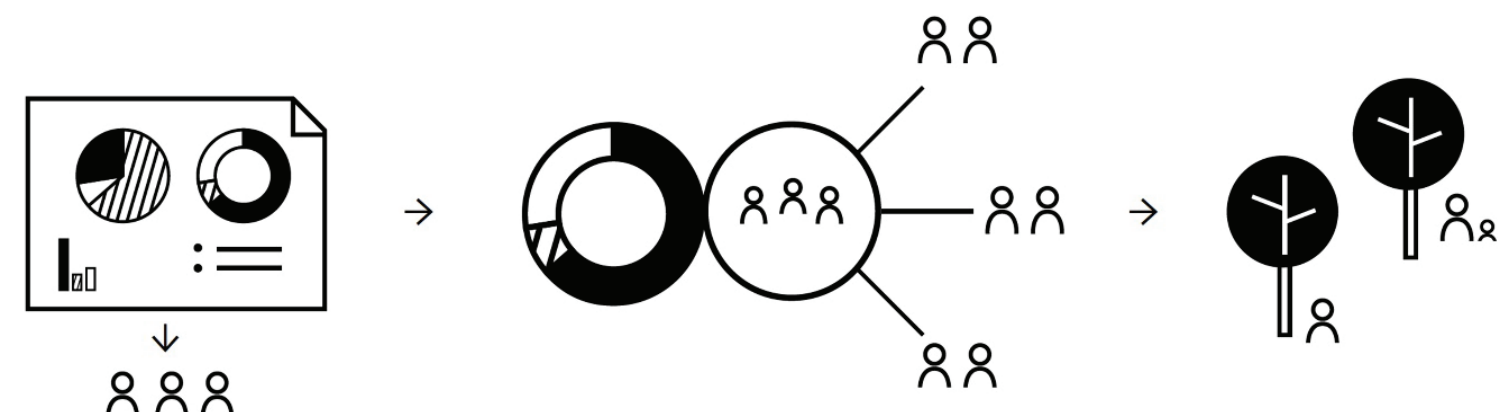

Present data

Listen and Expand

Re-ground

Figure 3. Phases of the co-creation process.

Table 3. MGD co-creation activities and timeline.

\begin{tabular}{lll}
\hline Activity & Purpose & Timing \\
\hline Focus groups & Deep mapping. & Autumn 2019 \\
Community launch event & $\begin{array}{l}\text { Presenting data and maps and gathering diverse insights in an } \\
\text { open way. }\end{array}$ & March 2020 \\
PLOTS tool & $\begin{array}{l}\text { Exploring the micro-geographies of the neighbourhood during the } \\
\text { Covid-19 lockdown. }\end{array}$ & Summer 2020 \\
Camac River Walk & $\begin{array}{l}\text { Camac go-along using Ubipix technology and GIS story-mapping } \\
\text { techniques exploring lack of access and experiences of the river. }\end{array}$ & Summer 2020 \\
Urban proto-typing workshop & Using design thinking to proto-type and develop projects for action. & August 2020 \\
\hline
\end{tabular}


155 comments were received and mapped geographically. During the workshop, Seoidín O'Sullivan ran a family-friendly event to map out emotional responses to particular trees. Maps developed during the participatory mapping event were also made available on the website and on social media and used to elicit further responses from the community using an online survey $(N=170)$. The nine interconnected dimensions of greening were synthesised under three main axes:

- Green environment (trees, greenspace, and biodiversity);

- Green amenity (play, sports, and seating/ benches);

- Green mobility (walking, cycling, and cars/ pollution).

A comprehensive set of recommendations ( $N=160$ ) was compiled from contributions made during the focus group event, individual comments made at the community launch and lunch dialogue workshop, and the comments received from the online community survey. Three synthesis maps and charts detailing the geographical locations and nature of these recommendations were created (see www.mappinggreendublin.com).

Due to Covid-19 lockdowns, alternative strategies were adopted to maximise engagement and the harnessing of local knowledge. In July 2020, the PLOTS tool was created by artist Seoidín O'Sullivan, and the community were invited using the My Map App or by hand-drawing to examine and map their individual microgeographies and the experience of local outdoor space during lockdown. Through this critical mapping of microgeographies, individuals commented on the changing local environment during lockdown, noticing reduced pollution, and the nature and quality (or lack thereof) of greenspace closest in (Browne, 2020; Rich, 1986) to their bodies and homes. When restrictions were lifted a group of individuals were taken on a critical mapping and walking exercise along the river Camac to highlight the lack of access along a large proportion of the riverside. A survey questionnaire and video technology (Ubipix) were utilised to gather visual and qualitative data from the walk and the data gathered was inputted into GIS story mapping software.

The final stage of the co-creation process overlapping with the action phase was the urban proto-typing workshop. In our study context, urban prototyping involved the framing, brainstorming, drawing out, designing, testing, and refining of ideas relating to the urban environment. This was attended by members of the neighbourhood greening forum, one of the key outputs of the project.

\subsubsection{Stage Three: Action}

Given the emphasis in MGD on community empowerment and leadership, an important action identified during the focus groups was the establishment of a neigh- bourhood greening forum. At our community launch event, 35 participants initially expressed interest and 13 became actively engaged. Members of the forum developed greening ideas anew or further developed and refined pre-existing ideas. The MGD team supported participants to develop their project ideas through design thinking methods at an outdoors urban prototyping workshop (Schiffer \& Clavin, 2020) in August 2020. Landscape architects, architects, an ecologist, and a city planner were invited to support community members to progress their thinking and leverage relationships with other stakeholders that could help convert project ideas into action. An urban proto-typing toolkit was developed as part of the action and is available on our project website (http://bit.ly/Urbanproto-typing) for widespread use.

Similar to the discussion in Cook and McGinn (2021b), our action phase also focused on building bridges beyond the community as a way to leverage support for the project goals beyond the project funding timeline. Qualitative semi-structured interviews were undertaken with key policymakers, practitioners, and landholders where the community recommendations arising from the co-creation stage and projects proposed by members of the greening forum were presented (Table 4). Following the urban proto-typing workshop and discussions within the forum, the rationale, approach, the desired outcome of each project, and the synergies between them had become much clearer. Three categories were developed, which could aid in identifying key audiences for the project and stakeholders.

To progress these projects, the MGD team opened up conversations with major landholders in the area such as the new National Children's Hospital and Digital Hub, presenting both scientific data but also alternate and local knowledges, in an attempt to build support and access space for the community proposals. From these engagements, barriers and opportunities to realising community desires were identified and policy recommendations in support of community-led greening were developed. As the key output, the community-led greening strategy (https://bit.ly/Communitygreeningstrategy) identifies eight pathways to change and meaningful action on greening. Through combining the community and policy insights, a set of actions to enhance and inform the provision, quality, use, and maintenance of green social infrastructure in Dublin 8 and beyond were identified. Thirteen actions, representing a greening agenda for the area, are the culmination of a co-creation process that is neither solely bottom-up or top-down, but rather works through different scales, knowledges, and practices.

\section{Sustaining Momentum}

Although the MGD project was time-limited, there was a desire by all involved that the approach and strategy would have longevity beyond the 24 months. A key part of the philosophy was not to present data regarding 
Table 4. Proposed projects developed by members of neighbourhood greening forum.

\begin{tabular}{ll}
\hline Project type & Project \\
\hline Intergenerational greenspaces & - Community garden (Inchicore) \\
& - Turvey Park sensory garden \\
& - Greenspace improvement on Devoy Road \\
& - Intergenerational private gardens \\
& - The Dublin 8 bench project \\
& - FUNAFLOAT: Water-based activity for young people along the Grand canal \\
Canal and walkway activity & - Grand Canal Towpath from Sally's Bridge to Drimnagh Luas stop \\
& - A pilgrim path, Camino: A walkway in Dublin 8 \\
Small projects with a big impact & - Parklets \\
& - Pocket forests (www.pocketforests.ie)
\end{tabular}

greening deficits, study the community, and then withdraw fully, but to ensure that an infrastructure was left in place to support ongoing engagement of the community with urban greening. MGD developed a particular type of local governance arrangement-the greening forum - which is grounded in and supported by scientific evidence, is strategic in nature, but is also transformative and dynamic in its thinking and actions. The group is open. Members consist of those who have already been involved in planning consultations, are known to the council and other landholding bodies, may have gone against plans and proposals and felt unheard (Abram, 2011), and also those who would not usually participate in public consultations or be involved in local groups. The actions of the forum are built on the deficits, potential, and opportunities identified through scientific and community mapping drawn out both from spatial analysis as well as through arts-based, creative practices. The forum is strategic as it is a recognisable structure where community members support one another, learn from the experiences of others, and from which they can engage more formally with landholders, policymakers, and others. It is transformative as it has used scientific data to engage with local decision-makers and successfully make the case to access space and develop projects on the ground, such as a well-used sensory garden developed at Turvey Park in the Summer of 2020, which is continuing to build momentum, and at least two pocket forests (a method of planting small biodiverse forests in urban areas) in the area. The greening forum operates informally on a number of different levels with the focus on action: often at small scales (e.g., planting of public spaces, activating blue spaces, and planting trees in gardens), knowledge sharing (online/offline), and with the ongoing support from both a community partner (Common Ground) engaged in critical and socially engaged creative practices and a local authority (Biodiversity Officer at DCC) that can lever relationships and action. This longer-term partnership structure should ensure that the group is included in state and municipality-led greening plans and initiatives, whilst also remaining embedded within local communities, and has access to a wider network of landowning stakeholders, NGOs, and academic institutions.

The development of a community greening forum is one way to ensure any greening plans are locally relevant, respond appropriately to community needs and are grounded in community action and empowerment. Supported by Common Ground going forward, the group can be part of a creative and inclusive form of civic engagement (Lund, 2018). However, the time investment required in adopting this approach to greening is significant and the skills required are often unavailable within the local government and planning structure. One critique of the project might be that through the production of a high-quality community-led greening strategy, community expectations are raised unrealistically. However, we would argue that our approach puts community empowerment front and centre. MGD was not about co-designing a wish list that cannot be fulfilled by local authorities, nor co-producing a particular output, but rather about co-creating a deliberative process through which communities can be empowered to engage for themselves. A central aspect of our community recommendations and the policymakers' reflections are that the governance of greening within the city is very fragmented and weak. There is therefore an imperative to consider alternative approaches to greening and the new urban actor constellations created through the MGD project. The 13 actions recommended may provide a pathway forward. This will require significant re-thinking of current structures and practices of greening and the development of much higher levels of trust between key decisionmakers and the local community. The disruption of binary roles and unequal power relations of expert/non-expert, researcher/researched, and local/outsider were transcended during the process through practising positionality and reflexivity (Schiffer, 2020). Whether this can be sustained and generate new systemic approaches is too early to say. What is clear is that the development of the strategy document is already having impact. The local authority is currently reviewing the City Development Plan and local councillors are advocating for the inclusion of some of our 
actions as strategic objectives within the new draft plan. The landscape architects within the city council are also currently revising the Liberties Greening Strategy and leaning heavily on our community greening strategyparticularly the scientific evidence base-for direction and ideas. Empowering communities with a strong scientific evidence base and the skills to engage with professionals in their language and through tools they recognise might therefore represent a new way for communities to participate and engage in local planning more effectively. Whether the contents of the greening strategy itself and the greening forum are compatible with future desires and aims of public consultation as carried out by the local authority and other bodies is still yet to be fully tested.

\section{Conclusion}

The co-creation process practiced was rich, deep, iterative, and also fruitfully messy and time-consuming. It began as a collaboration between academics, artists, activists, and designers and culminated with a wider community of residents, policy makers, practitioners, and interested individuals. Rather than viewing the co-creation process as a panacea for the ongoing issues around engagement in planning and design processes, it can add value to other critical practices and research approaches. The key outcomes-the strategy itself and the greening forum-are a lasting legacy. The strategy provides an evidence base for greening deficits and for what the community wants, and the greening forum provides a space for those who are active but may have felt unheard in previous consultations, plus those who do not usually engage. The new actor constellations produced work through top-down and bottom-up processes and aim to critically and creatively work through the space between a more abstract model of participatory or collaborative planning, and the inspiring but specific ad-hoc actions that usually arise from certain specific people and personalities. The initiatives created by members of the forum are ongoing, address neighbourhood need, and inspire action into the future. The model for the forum ensures that the group is open to new members and supported by appropriate expertise and encouraged to be creative in developing and experimenting with new ideas and practices for a more resilient community.

International debates on resilient and sustainable communities and active citizenship have been magnified during this project and particularly due to the Covid-19 pandemic. The importance of trees and greenspace nearest to residences for physical and mental health and wellbeing has become more evident during public health mobility restrictions. Despite this evidence, greening is still often an after-thought within a developer-led planning system, as exemplified in Dublin, and there is still a heavy reliance on ad-hoc greening initiatives with an idealised notion of the public and how public engagement can occur with a top-down approach. A more sig- nificant contribution from local greening fora is the missing link in ensuring communities can articulate their greening needs and that greening plans are appropriate and optimise impact. This however requires significant time investment by all parties, a recognition that trustbuilding is a slow process, and a willingness to disrupt traditional dynamics and engage in new ways of working. This is particularly the case in historically disadvantaged communities where there has been a history of fraught dynamics with, for example, local authorities and a feeling that an area is under constant development pressure. Academics, artists, and place-based community organisations can become critical supporters and interlocutors empowering groups through access to science, responding to community needs and then later bridging out to other stakeholders. These new actor constellations open up dynamic new spaces of urban governance and action that are critical to achieving more inclusive, just, and sustainable cities.

\section{Acknowledgments}

This project is funded under the Irish Environmental Protection Agency Research Programme 2021-2030. The Irish Environmental Protection Agency Research Programme is a Government of Ireland initiative funded by the Department of the Environment, Climate, and Communications. The authors would like to acknowledge the support of the project funders and project partners Common Ground, Seoidín O'Sullivan, and Connect the Dots, as well as the contributions of community participants and the project steering group. Thanks to the two anonymous referees for their insightful feedback on an earlier draft and to Ruth Martin who co-designed the project graphics.

\section{Conflict of Interests}

The authors declare no conflict of interests.

\section{References}

Abram, S. (2011). Culture and panning. Ashgate.

Agyeman, J. (2013). Introducing just sustainabilities: Planning, policies and practice. Zed Books.

Alford, J. (2009). Engaging public sector clients: From service delivery to co-production. Palgrave Macmillan.

Amin, A. (2013). Telescopic urbanism and the poor. City, 17(4), 476-492.

Anguelovski, I., Brand, A. L., Connolly, J. J. T., Corbera, E., Kotsila, P., Steil, J., Garcia-Lamarca, M., TrigueroMas, M., Cole, H., Baró, F., Langemeyer, J., del Pulgar, C. P., Shokry, G., Sekulova, F., \& Ramos, L. A. (2020). Expanding the boundaries of justice in urban greening scholarship: Toward an emancipatory, antisubordination, intersectional, and relational approach. Annals of the American Association of Geographers, 110(6), 1743-1769. 
Anguelovski, I., Connolly, J. J., Garcia-Lamarca, M., Cole, H., \& Pearsall, H. (2019). New scholarly pathways on green gentrification: What does the urban "green turn" mean and where is it going? Progress in Human Geography, 43(6), 1064-1086.

Bodenhamer, D., Corrigan, J., \& Harris, T. (Eds.). (2015). Deep maps and spatial narratives. Indiana University Press.

Brickford, S. (1996). The dissonance of democracy: Listening, conflict and citizenship. Cornell University Press.

Browne, K. (2020). The geographies closest in: Intimate geographies and/of Covid-19. Irish Geography, 53(2), 151-156.

Brudell, P. (2014). The role of private consultancies in neoliberal urban regeneration. In A. McLaren \& S. Kelly (Eds.), Neoliberal urban policy in Dublin and the transformation of the city (pp. 233-249). Palgrave Macmillan.

Carmichael, C. E., \& McDonough, M. H. (2018). The trouble with trees? Social and political dynamics of street tree-planting efforts in Detroit, Michigan, USA. Urban Forestry \& Urban Greening, 31, 221-229.

Central Statistics Office. (2016). Census 2016 reports. https://www.cso.ie/en/census/census2016reports

Cole, H. V. S., Triguero-Mas, M., Connolly, J. J. T., \& Anguelovski, I. (2019). Determining the health benefits of green space: Does gentrification matter? Health \& Place, 57, 1-11.

Common Ground. (2019). Studio 468 citizen artist 2016-2018. https://issuu.com/cgpublish/docs/ citizenartist_174x249mm_page01-80_lowres

Cook, I. M., \& McGinn, K. (Hosts). (2021a, February 3). Drivers of urban justice (No. 12) [Audio podcast episode]. In Urban Arena. UrbanA. https://urbanarena.eu/resources/\#publications

Cook, I. M., \& McGinn, K. (Hosts). (2021b, March 1). Participation and the distribution of urban space (No. 13) [Audio podcast episode]. In Urban Arena. UrbanA. https://urban-arena.eu/resources/ \#publications

Cook, I. R. (2008). Mobilising urban policies: The policy transfer of US business improvement districts to England and Wales. Urban Studies, 45(4), 773-795.

Cooke, B., \& Kothari, U. (Eds.). (2001). Participation: The new tyranny? Zed Books.

Datta, A. (2013). Encounters with law and critical urban studies: Reflections on Amin's telescopic urbanism. City, 17(4), 517-522.

de Sousa Santos, B. (2014). Epistemologies of the South: Justice against epistemicide. Routledge.

de Sousa Santos, B. (2018). The end of the cognitive empire: The coming of age of epistemologies of the South. Duke University Press.

Donetto, S., Pierri, P., Tslanakas, V., \& Robert, G. (2015). Experience based co-design in healthcare improvements: Realizing participatory design in the public sector. The Design Journal, 18(2), 227-248.

Dublin City Council. (2015). The liberties greening strategy. https://www.dublincity.ie/sites/default/ files/2021-02/liberties-greening-strategy_0.pdf

Ermacora, T., \& Bullivant, L. (2016). Recoded city: Co-creating urban futures. Routledge.

Fawcett, P., \& Marsh, D. (2014). Depoliticisation, governance and political participation. Policy \& Politics, 42(2), 171-188.

Flinders, M., \& Wood, M. (2014). Depoliticisation, governance and the state. Policy and Politics, 42(2), 135-149.

Florida, R. (2002). The rise of the creative class. Basic Books.

Giddens, A. (1984). The constitution of society: Outline of the theory of structuration. University of California Press.

Grodach, C. (2017). Urban cultural policy and creative city making. Cities, 68, 82-91.

Harvey, D. (1989). From managerialism to entrepreneurialism: The transformation in urban governance in late capitalism. Geografiska Annaler: Series B, Human Geography, 71(1), 3-17.

Healey, P. (1997). Collaborative planning: Shaping places in fragmented societies. Macmillan International Higher Education.

Healey, P. (2003). Collaborative planning in perspective. Planning Theory, 2(2), 101-123.

Hollander, J. B., Graves, E., Renski, H., Foster-Karim, C., Wiley, A., \& Das, D. (2016). Urban social listening potential and pitfalls for using microblogging data in studying cities. Palgrave Macmillan.

Horvath, C., \& Carpenter, J. (Eds.). (2020). Co-creation in theory and practice: Exploring creativity in the Global North and South. Policy Press.

Innes, J. E. (1998). Information in communicative planning. Journal of the American Planning Association, 64(1), 52-63.

International Society of City and Regional Planners. (2009). Urban planning and human health in the European city: Report to the World Health Organisation. https://isocarp.org/app/uploads/2014/08/ WHO_report_final_version.pdf

Kayanan, C., Moore-Cherry, N., \& Clavin, A. (2021). Cities under lockdown: Public health, urban vulnerabilities and neighbourhood planning in Dublin. In B. Doucet, R. Filion, \& R. Van Melik (Eds.), Global reflections on Covid 19 and urban inequalities: Housing and home (Vol. 2, pp. 189-198). Bristol University Press.

Kelly, S. (2014). Taking liberties: Gentrification as neoliberal policy in Dublin. In A. McLaren \& S. Kelly (Eds.), Neoliberal urban policy in Dublin and the transformation of the city (pp. 174-188). Palgrave Macmillan.

Landry, C., \& Bianchini, F. (1995). The creative city. Demos.

Lawton, P. (2017). Idealizing the European city in a neoliberal age. In J. Hanigan \& G. Richards (Eds.), The SAGE handbook of new urban studies (pp. 78-91). SAGE.

Lawton, P. (2019). Design, density and the building of 
landscape. Building Material, 22, 189-206.

Lees, L., \& Melhuish, C. (2015). Arts-led regeneration in the UK: The rhetoric and the evidence on social inclusion. European Urban and Regional Studies, 22(3), 242-260.

Lund, D. H. (2018). Co-creation in urban governance: From inclusion to innovation. Scandinavian Journal of Public Administration, 22(2), pp. 3-17.

McCann, E., \& Ward, K. (2012). Assembling urbanism: Following policies and "studying through" the sites and situations of policy making. Environment and Planning A: Economy and Space, 44(1), 42-51.

Moore, N. (2008). Dublin docklands reinvented: The postindustrial regeneration of a European city quarter. Four Courts Press.

Moore-Cherry, N. (2017). Beyond art in "meanwhile spaces:" Temporary parks, urban governance and the co-production of urban space. In M. Murzyn-Kupisz \& J. Dzlaiek (Eds.), The impact of artists on contemporary urban development in Europe (pp. 207-224). Springer.

Moore-Cherry, N., Copeland, A., Denker, M., Murphy, N., \& Bhriain, N. N. (2019). The playful city: A tool to develop more inclusive, safe and vibrant intergenerational urban communities. In M. Besters (Ed.), Our city? Countering exclusion in public space (pp. 269-277). STIPO.

Moore-Cherry, N., Crossa, V., \& O'Donnell, G. (2015). Investigating urban transformations: GIS, mapelicitation and the role of the state in regeneration. Urban Studies, 52(12), 2134-2150.

Mouffe, C. (2007). Artistic activism and agonistic spaces. Art \& Research: A Journal of Ideas, Contexts and Methods, 1(2). http://www.studio55.org.uk/anr/ v1n2/mouffe.html

Musterd, S., \& Kovács, Z. (Eds.). (2013). Place-making and policies for competitive cities. Wiley.

Oscilowicz, E., Lewartowska, E., Levitch, A., Luger, J., Hajtmarova, S., O'Neill, E., Planas Carbonell, A., Cole, H., Rivera Blanco, C., \& Monroe, E. (2021). Policy and planning tools for urban green justice: Fighting displacement and gentrification and improving accessibility and inclusiveness to green amenities. Barcelona Laboratory for Urban and Environmental Justice and Sustainability (BCNUEJ).

Phillips, P. (2000). Out of order: The public art machine. In M. Miles, T. Hall, \& I. Borden (Eds.), The city cultures reader (pp. 96-102). Routledge. (Original work published in 1988)

Punch, M. (2014). Contested urban environments: Community engagement and struggle in central Dublin. In A. McLaren \& S. Kelly (Eds.), Neoliberal urban policy in Dublin and the transformation of the city (pp. 249-265). Palgrave Macmillan.

Rich, A. (1986). Blood, bread, and poetry: Selected prose 1979-1985. W.W. Norton \& Company.

Roberts, L. (2016). Deep mapping and spatial anthropology. Humanities, 5(1), Article 5.

Rotherham, I., \& Flinders, M. (2019). No stump city: The contestation and politics of urban street-treesA case study of Sheffield. People, Place and Policy Online, 12(3), 188-203.

Schiffer, A. (2020). Issues of power and representation: Adapting positionality and reflexivity in communitybased design. International Journal of Art \& Design Education, 39(2), 418-429.

Schiffer, A., \& Clavin, A. (2020). Mapping Green Dublin: Urban prototyping with communities. University College Dublin.

Schlosberg, D. (2013). Theorising environmental justice: The expanding sphere of a discourse. Environmental Politics, 22(1), 37-55.

South Inner-City Community Development Association. (2019). Community profile and needs assessment of the liberties and surrounding areas.

Steinhaus, L., Schields, M., Schrammel, M., \& Feichtinger, J. (2018). Guidebook on engagement and co-creation methodologies (BLOOM Report D3.3). WILA Bonn.

Swyngedouw, E., Moulaert, F., \& Rodriguez, A. (2002). Neoliberal urbanization in Europe: Large-scale urban development projects and the new urban policy. Antipode, 34(3), 542-577.

Triguero-Mas, M., Anguelovski, I., García-Lamarca, M., Argüelles, L., Perez-del-Pulgar, C., Shokry, G., Connolly, J. J. T., \& Cole, H. V. S. (2021). Natural outdoor environments' health effects in gentrifying neighborhoods: Disruptive green landscapes for underprivileged neighborhood residents. Social Science \& Medicine, 279, Article 113964. https://doi.org/ 10.1016/j.socscimed.2021.113964

Van Melik, R., \& Lawton, P. (2011). The role of public space in urban renewal strategies in Rotterdam and Dublin. Planning Practice and Research, 26(5), 513-530.

Yúdice, G. (2003). The expediency of culture: Uses of culture in the global era. Duke University Press.

\section{About the Authors}

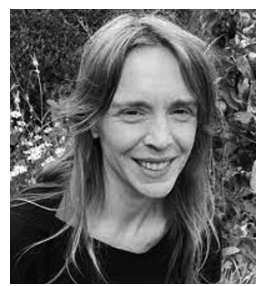

Alma Clavin (PhD) is an urban geographer and social sciences researcher at the University College Dublin's School of Geography. Currently her main research activity involves engaging with practitioners and theorists to enhance critical participative enquiry in everyday urban environments. Alma continues to research and work with inner city communities to explore local greening deficits and the particular health and wellbeing impacts of greening for residents living in high density housing complexes. 


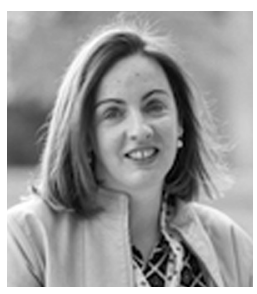

Niamh Moore-Cherry is an associate professor in urban governance and development at the School of Geography, University College Dublin, and honorary professor at the Bartlett School of Planning, University College London. Her research is focused on understanding the governance of urban (re-)development, and metropolitanisation and its outcomes. Niamh leads a team in UCD School of Geography examining the relationship between cities, governance, and sustainability, and has significant experience in working at the policy-practice-research nexus in Ireland, the UK, and at EU level.

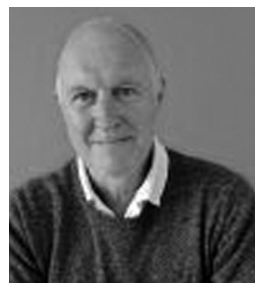

Gerald Mills is an associate professor of geography at the School of Geography, University College Dublin. He is a physical geographer with interests in the urban environment and the climates of cities. Much of his recent work has focussed on Dublin's urban forest, the gaps in coverage, and the environmental services that it provides. 